\title{
The influence of support program in the development of thermal irrigation canal on rice production improvement in Pohuwato District
}

\author{
Amir Halid*; Muh. Amir Archam; Sri Astuti Manoppo \\ Agribusiness Study Department, Post Graduated Program, \\ Universitas Negeri Gorontalo, Indonesia \\ *To whom correspondence should be addressed.Email: amirhalid_ung@yahoo.com
}

\begin{abstract}
The purposes of this research are: 1) to analyze the implementation system of tertiary irrigation assistance in Pohuwato District, 2) To study the tertiary irrigation development assistance program that affect the increase of rice production in Pohuwato. The study was conducted in Pohuwato District with 93 farmers sample. The research method used is survey method. Data analysis used is descriptive analysis with percentage formula and multiple linear regression analysis. The results showed that the system of tertiary irrigation implementation from the assessment of the percentage of total score of respondents answers on the program policy indicators included in the category is quite good, and on the indicator of increased production percentage total score of respondents' answers included in the category very well. So that the application of tertiary irrigation aid in the research location has been well developed in the aid of tertiary irrigation canal program. The results that the program of development assistance of tertiary irrigation canals on rice farming simultaneously have a positive and significant effect on increasing rice production. While partially independent variable (program policy, farmer institute, and tertiary irrigation canal) to dependent variable of rice production.
\end{abstract}

Keywords: Irrigation canal, Rice farming production, farmer

JEL Classification: Q15, Q18

\section{INTRODUCTION}

Agriculture is an important sector in economic development, to givethe function and role in the provision of food and energy for the population, where rural livelihoods depend on it, the Agricultural Sector has a significant contribution in the formation of Gross Domestic Product (GDP), increased foreign exchange and increased welfare of farmers, so that the development of agriculture can be regarded as the driven of national economy and support, (Ministry of Agriculture, 2014).

Infrastructure and facilities are one important factor in the farming process, such as irrigation infrastructure. Irrigation infrastructure determines the availability of water that directly impacts the quality and quantity of crops, especially rice crops (Ministry of Agriculture, 2014).

The paddy field printing program in Pohuwato District has been successful in supporting the increase of rice production. This can be measured from the increase of rice production which is sourced from the addition of planted area which is sourced from the paddy field printing activity, in which the amount of paddy production that has 
been reached by Pohuwato reaches 38,241 ton, then in $2012(16.94 \%)$ increased to 44,720.63 tons, in 2013 (1.63\%) 45,461 tons, in $2014(0.43 \%)$ 45,658.44 tons and in $2015(0.42 \%)$ 45,850.03 ton (Agricultural Service of Gorontalo Province, 2017).

Based on data on average of rice production in PohuwatoDistrict for the last five years, the highest increase of production occurred in 2015 compared to several years before. One of the causes of the high increase of production is the utilization of paddy field that was carried out in 2012, which was implemented in 2016 has not contributed to the increase of rice production in Pohuwato District, because the rice field has not been utilized optimally because it is still temporarily waiting for the completion of irrigation development which is currently the ongoing implementation.

The area of irrigation canal in Pohuwato District in 2013 reached by 300 ha, then in 2014 the area of irrigation canal has increased up to 1,000 ha, by 2015 the area of irrigation canal is 2,200 ha, and by 2016 the area of irrigation canal is 1,650 ha. In addition, the state of paddy production in Pohuwato District in 2012 reached 245.786 tons, production in 2013 of 295.913 tons, in 2014 rice production of 314.703 tons, in 2015 production reached 331.220 tons, and in 2016 production of 337.330 tons. Production of paddy in Pohuwato District every year has increased production, it is because of the assistance of tertiary irrigation program in development (Agricultural Service of Gorontalo Province, 2017).

From the backgroundabove, the purposes of this research are 1) to analyze the implementation of tertiary irrigation development assistance program system in Pohuwato District, 2) to examine the effect of tertiary irrigation development assistance program on increasing rice production in Pohuwato District.

\section{LITERATURE REVIEW}

Pakistan is vulnerable to climate change, and extreme climatic conditions are threatening food security. This study examines the effects of climate change (e.g., maximum temperature, minimum temperature, rainfall, relative humidity, and the sunshine) on the major crops of Pakistan (e.g., wheat, rice, maize, and sugarcane). The methods of feasible generalized least square (FGLS) and heteroscedasticity and autocorrelation (HAC) consistent standard error were employed using time series data for the period 1989 to 2015 . The results of the study reveal that maximum temperature adversely affects wheat production, while the effect of minimum temperature is positive and significant for all crops. Rainfall effect towards the yield of a selected crop is negative, except for wheat. To cope with and mitigate the adverse effects of climate change, there is a need for the development of heat- and drought-resistant high-yielding varieties to ensure food security in the country (Ali, 2017).

This present Technical Manual for Irrigable Lowland Development in Liberia prepared by the Ministry of Agriculture is the result of several years of practical work in the field, including data collection, construction activities, cultivating of rice fields as well as training and capacity building with the farmers' communities The objective of this manual is to condense the existing knowledge and the expertise gained during actual field work period and to make it available to more actors in the field. The manual is structured in five chapters: the first two chapters provide the rationale and justification for shifting from upland to lowland farming with an overview of the nature and potential of lowlands; the third and central chapter gives practical explanations and good practices regarding the engineering side of lowland development and rehabilitation. The last two chapters $(4 \& 5)$ tackle supplementary issues like water management and maintenance of lowland schemes. The authors firmly believe that 
lowland farming offers a very valid alternative to the present slash and burn shifting cultivation on the uplands which, under certain circumstances, can lead to deforestation and destabilization of the environment The upland farming of a growing population has a limited agricultural production potential and threatens Liberia's food security and wealth in rich forest resources (MOA technical team, 2015).

Potential future impacts of climate change on irrigated rice and wheat production and their evapotranspiration and irrigation requirements in the Gomti River basin were assessed by integrating a widely used hydrological model "Soil and Water Assessment Tool (SWAT)" and climate change scenario generated from MIROC (HiRes) global climate model. SWAT model was calibrated and validated using monthly streamflow data of four spatially distributed gauging stations and district wise wheat and rice yields data for the districts located within the basin. Simulation results showed an increase in mean annual rice yield in the range of 5.5-6.7, 16.6-20.2 and 26-33.4\% during 2020s, 2050 s and 2080s, respectively. Similarly, mean annual wheat yield is also likely to increase by $13.9-15.4,23.6-25.6$ and $25.2-27.9 \%$ for the same future time periods. Evapotranspiration for both wheat and rice is projected to increase in the range of 3-9.6 and $7.8-16.3 \%$, respectively. With increase in rainfall during rice growing season, irrigation water allocation for rice is likely to decrease $(<5 \%)$ in future periods, but irrigation water allocation for wheat is likely to increase by $17.0-45.3 \%$ in future periods (Abeysingha, 2016).

ocTrang (in Mekong River Delta) for saline intrusion problems and TraVinh province for drought, where selected measures are being pilot tested for their potential adaptation and mitigation impacts, and their performance being validated in cooperation with local agencies and farmers. The project results will indirectly support the MARD strategy for agricultural development, as well as the ARD Action Plan to Climate Change. The wide network of agricultural and extension agencies located across the country under VAAS will be used for dissemination of project results. The interdisciplinary approach in the project will help to address the main concerns in rice production, besides emphasis on stakeholder interaction (farmers, women groups, government authorities, private sector) from the beginning of the project. This is also to ensure strengthening of science-policy linkage in the project. The main goal of the ClimaViet project is to identify and pilot test climate smart rice farming systems that will contribute to improve rice production under changing climate, and at the same time help in mitigation of greenhouse gases (GHGs). His report will provide a benchmark survey of the three study areas including the future climate scenarios in brief, a socioeconomic profile of the areas, and the main challenges and government initiatives to address climate change impacts in the three provinces. It will start with an introduction, followed by three sections presenting the three different regions (trinh, 2014).

The previous study from four references above, in general discuss about the climate change that can cause some problem of agriculture commodity that limited of the production process. It is important to solve with some systems of cultivation and irrigation water allocation and it can develop the areas of farmer in some country. This are some of literature explain in the following text:

Water is one of the main factors in the process of agricultural production. Therefore, irrigation investment becomes very important and strategic in the framework of water supply for agriculture. In meeting the water needs for various farming purposes, water (irrigation) should be given in the amount, and the right quality, otherwise the plant will be disturbed its growth which in turn will affect agricultural production (Directorate of Water Management, 2010). 
Upstream and downstream water supplies require adequate irrigation facilities and infrastructure. The facilities and infrastructure may include: dams, primary and secondary ducts, storage boxes, measuring buildings, and tertiary channels and level channels (TUT), Terangganggunya or destruction of one of the irrigation buildings will affect the performance of the existing system, resulting in the efficiency and effectiveness of irrigation to decline, If this condition is allowed and not immediately addressed, it will have an impact on the expected decline in agricultural production, and has negative implications for farmers' income conditions and social, economic conditions around the site (Directorate of Water Management, 2010).

Institutions are all ideal patterns, organizations, and activities centered around basic needs such as family, country, religion and food, clothing and pleasure and shelter. An institution is formed always aimed to meet various human needs so that the institution has a function. In addition, the institution is a concept that combines with the structure, meaning that not only involves socially-born patterns of activity to meet human needs, but also organizational patterns to implement them (Roucek and Warren, 1984).

Other opinions are also raised by (Suradisastra, 2008), capacity building of farmers and institutional groups of farmers is needed in an effort to improve the competitiveness of farmers in the development of agribusiness system in Indonesia. This effort is increasingly needed in the face of the era of globalization and free trade. The capacity of farmers to increase in line with their participation in farmer institutions will encourage institutional capacity to be more effective. In the life of the peasant community, the position and function of the farmer's institution is part of the social order that facilitates social interaction or social interplay within a community.

From some of the above understanding, the authors can conclude that the institutional agriculture is a community of farmers, positions and institutional functions of farmers in managing resources in rural areas with which can create jobs and improve the opinion of farmers.

a. Farmer Group

Roekasah (2004), farmer group is aassociation of farmers/farmers/planters established on the basis of equality of interests, the similarity of environmental conditions (social, economic, resources) and familiarity to improve and develop member businesses. The guidance of farmer groups is directed to the application of agribusiness system, increasing the role, participation of farmers and other rural community members, by developing cooperation between farmers and other related parties to develop their farm business. In addition, coaching farmer groups is expected to help explore potentials, solve problems of farming members more effectively, and facilitate in accessing information, markets, technology, capital, and other resources.

b. Gapoktan

Gapoktan is a combination of several groups of farmers who do business agribusiness on the principle of togetherness and partnership to achieve increased production and income farming for its members and other farmers. The main objective of establishing and strengthening Gapoktan is to strengthen the existing farmers' institutions, so that the government's guidance to farmers will be clearly targeted (Deptan, 2006).

Agriculture Production Facility Means production required in rice farming other than land, and labor generally are seeds, fertilizers, and medicines for good rice production so that maximum profit can be achieved need to be given the appropriate input in accordance with their needs, the way of giving, the dose must also be precise, 
all of which is also added with the selection of seeds, seeding, soil processing, weeding, fertilization, and pest eradication, All of the above is commonly referred to as technology, The use of production inputs with existing technology can be optimized to achieve same purposes, the purpose of production is the maximum profit level, the production process of rice farming required some kind of input commonly called the means of production (Daniel, 2004).

Institutions are a set of rules used (work rules or rules that are actually used) by a number of individuals to organize repeated activities that produce results that affect all such individuals and potentially affect others (Agustina, 2011).

$\mathrm{P} 3 \mathrm{~A}$ is one of the local organization which is a means of interaction and cohesiveness among members of the farming community as one social unit called water user farmer commodities. This commodity facilitates its members to interact mutually support and institutionalized within a social organization and at the same time as a venue that embodies the interests of each member into a common goal at the local community level. Social organizations are equipped with a set of norms that govern the structure and role. The P3A's organizational function is to encourage the members to regulate the regular and efficient use of water. This can be achieved given that the organization is a feature of social life consisting of canals, norms, trusts, capable of mobilizing the participation of group members to achieve common goals (Helmi, 2007).

With the issuance of Presidential Instruction No. 3 of 1999, IPAIR is no longer deposited to the District / municipal Dispenda, but is fully managed by the Joint P3A whose working area includes one secondary channel and the Federation P3A whose working area covers one primary channel (Trisno, 2009: 5). Agustina (2011) who views P3A from its functions and advantages, states that the P3A social nature still needs to be maintained, because: 1) The ownership of water use rights and irrigation by P3A member farmers is collective; 2) WUA can serve as an instrument to create and maintain the economic equality among farmers; 3 ) Technically will require very serious institutional change effort, given the social nature of P3A that has been embedded in the policies and regulations concerning the management of WUA.

Thus, the strategy step that must be done is to combine business perspective in the framework of P3A vision that is social. The implication is the need to adjust the institutional structure of $\mathrm{P} 3 \mathrm{~A}$ which refers to the perspective of regional autonomy.

\section{METHODS}

This research conducted in Pohuwato District, Gorontalo Province. The location of this study was chosen because generally farmers in the location mostly got access to irrigation canal in paddy field in Pohuwato District.

Research design is survey study. The data used in research that is primary data and secondary data. Primary data were obtained from interviews and fusion dried by farmers of rice field farmers respondents in Pohuwato District. Secondary data is obtained from official reports from relevant agencies in this case such as Gorontalo Central Bureau of Statistics (BPS), and other agencies that can assist in providing data.

The population in this study selected several sub-districts namely Popayato District, Taluditi Sub-district, Randangan District, Buntulia District and Duhiadaa Subdistrict in Pohuwato District which was determined by purposive sampling technique or intentionally because the five sub-districts had conducted initial survey so it was feasible to be designated as research area. The total population in the five districts is 2,208 people. 
Respondent farmer's research in this research is done by random sampling (random sampling) with total population as much as 2.208 peasant farmer. One way to get a representative sample is by a process called random sampling. Associated with the large sample to be taken, Slovin proposed a formula for determining the size of the sample, thus samples taken as many as 93 respondents from 21208 or rice farming:

The data analysis method that used in this research is descriptive analysis method, which is to explain in detail about the system of application of tertiary irrigation aid in Pohuwato District.

As a phenomena, the data tool measured used is Likert Scale. Likert scale is used to measure attitudes, opinions and perceptions of a person or a group of social phenomena, In Likert scale the variable to be measured is translated into indicator variables, then the indicator is used as a starting point to arrange the items of instruments that can be questions or statements. In this study the authors use 5 levels.

The percentage score obtained by each indicator shows the system of tertiary irrigation aid implementation to the increase of paddy rice production in Pohuwato by Subagio classification (in MoNE, 2008) as in the following table:

Table 1. Classification score percentage of tertiary irrigation development assistance program to increase rice production

\begin{tabular}{ccc}
\hline Number & Percentage of Score & Classification \\
\hline 1 & $85 \% \mathrm{~s}, \mathrm{~d} 100$ & Very Good \\
2 & $76 \%-84 \%$ & Good \\
3 & $56 \%-75 \%$ & Fair \\
4 & $40 \%-55 \%$ & Poorly \\
5 & $0 \%-39 \%$ & Bad \\
\hline
\end{tabular}

For the identification of problem 2, it was analyzed by using multiple linear regression analysis to know the influence of labor usage and land area of paddy rice production, with formula:

$$
Y=a+b_{1} X_{1}+b_{2} X_{2}+D
$$

$\mathrm{Y} \quad=$ Increasing of Rice Production

A $\quad=$ Constant Number

$\mathrm{b} \quad=$ Regression Coefficient

$\mathrm{X}_{1} \quad=$ Program Policy

$\mathrm{X} 2 \quad=$ Farmer Institutional

$\mathrm{D} \quad=$ Tertiary Irrigation Canal $\left(\mathrm{D}_{\mathrm{JI}}=1\right.$, Tertiary Irrigation; $\mathrm{D}_{\mathrm{JI}}=0$, Non Tertiary Irrigation).

To facilitate the data collection, showed in the operational concept of variables as follows:

1. Rice Production is the amount of production produced by each farmer during one planting season (MT) that is on MT, I, MT, II, and MT, III,

2. Production (Y) is an activity to increase the value of an object or to create a new object so that it is more useful in meeting the needs, in units $(\mathrm{Rp}) /$ harvest,

3. Irrigation land is land that get for water need from irrigation canal,

4. Non-irrigated land (rainfed) is land that gets its water requirement solely from rainfall,

5. Program policies that refers to the goals, targets and strategies of the program for agricultural development continue to be driven, mainly in order to pursue increased production, added value and welfare of farmers, 
6. The farmer institution is a growing institution developed from, by, and for farmers, established on the basis of equality of interests, the equality of social, economic, and resource conditions,

7. Irrigation is the business of providing, arranging, and disposing irrigation water to support agriculture which kind includes surface irrigation, swamp irrigation, underground water irrigation, pump irrigation, and pond irrigation,

8. Tertiary Irrigation Canal is a canal of irrigation water in tertiary plots, from the outer waters of tertiary measurement buildings, consisting of tertiary and quarterly channels including tertiary and quartile divisions, and other complementary buildings contained in the plot.

\section{RESULT AND DISCUSSION}

\section{Systems for implementation of tertiary irrigation support}

Systems for Implementation of Tertiary Irrigation Support from Assessment of Program Policy of Respondents results regarding program policy indicators can be presented in the Table 2.

Table 2. Respondent answer percentage of indicator program policy in implementation of tertiary irrigation support in Pohuwato District, 2017

\begin{tabular}{|c|c|c|c|c|c|c|}
\hline \multirow[b]{2}{*}{ No. } & \multirow[b]{2}{*}{ Question } & \multicolumn{5}{|c|}{ Respondents Answer Score (\%) } \\
\hline & & $\begin{array}{c}5 \\
\text { (Very } \\
\text { Know) }\end{array}$ & $\begin{array}{c}4 \\
\text { (Know) }\end{array}$ & $\begin{array}{c}3 \\
\text { (Know } \\
\text { Enough) }\end{array}$ & $\begin{array}{c}2 \\
\text { (Doubtful) }\end{array}$ & $\begin{array}{c}1 \\
\text { (Do Not } \\
\text { Know }\end{array}$ \\
\hline 1 & $\begin{array}{l}\text { Have you ever been involved in the } \\
\text { socialization of a tertiary irrigation } \\
\text { development assistance program? }\end{array}$ & 44.0 & 31.1 & 16.1 & 3.22 & 5.37 \\
\hline 2 & $\begin{array}{l}\text { Is the method and technical } \\
\text { socialization of the tertiary irrigation } \\
\text { development assistance program easy } \\
\text { to understand? }\end{array}$ & 64.5 & 15.0 & 8.6 & 7.52 & 4.3 \\
\hline 3 & $\begin{array}{l}\text { Do you know and understand the } \\
\text { purpose of the tertiary irrigation } \\
\text { development assistance program? }\end{array}$ & 64.5 & 12.9 & 12.9 & 7.52 & 2.15 \\
\hline 4 & $\begin{array}{l}\text { Do you know and understand the } \\
\text { target of the tertiary irrigation } \\
\text { development assistance program? }\end{array}$ & 13.9 & 39.7 & 9.67 & 27.9 & 8.6 \\
\hline 5 & $\begin{array}{l}\text { Do you know and understand the } \\
\text { strategy of the tertiary irrigation } \\
\text { development assistance program? }\end{array}$ & 10.7 & 5.37 & 15.0 & 17.2 & 51.6 \\
\hline
\end{tabular}

Source: Field Study, 2017

Based on Table 2 above, the percentage of respondents answers to the first question answered the respondent farmers very know is $44 \%$, enough to know is $31.1 \%$, know is $16.1 \%$, hesitant $3.22 \%$, and do not know is $5.37 \%$. Then the second question answered the respondent's farmers very know is $64.5 \%$, enough know $15 \%$, know is $8.60 \%$, hesitate is $7.52 \%$, and do not know is $4.30 \%$. For the third question the respondent answers very much is $64.5 \%$, know enough $12.9 \%$, know is $12.9 \%$, hesitate is $7.52 \%$, and do not know is $2.15 \%$. Then for the fourth question respondents really know is $13.9 \%$, quite know is $39.7 \%$, know is $9.67 \%$, hesitate is $27.9 \%$, and do not 
know is $8.60 \%$. For the fifth question respondent's answer really know is $10.7 \%$, enough know is $5.37 \%$, know is $15 \%$, hesitate is $17.2 \%$, and do not know is $51.6 \%$.

In terms of percentage of respondents answers this indicates that farmers are involved in socialization, farmers understand the mechanism and technical socialization, farmers understand the objectives, targets, and program strategies implemented in the development assistance of tertiary irrigation, although there are still farmers who never applied irrigation assistance tertiary through program policies implemented at the research site, it is because the farmers rice fields are in the swamp waters and some are located in the waters of lake.

\section{Implementation of tertiary irrigation support from assessment of farmers instutional}

The results of the responses of respondents on the institutional indicators of farmers can be presented in the following Table:

Table 3. Respondent answer percentage of indicator farmers instutional in implementation of tertiary irrigation support in Pohuwato District, 2017

\begin{tabular}{|c|c|c|c|c|c|c|}
\hline \multirow[b]{2}{*}{ No. } & \multirow[b]{2}{*}{ Question } & \multicolumn{5}{|c|}{ Respondents Answer Score (\%) } \\
\hline & & $\begin{array}{c}5 \\
(\text { Very } \\
\text { Know) }\end{array}$ & $\begin{array}{c}4 \\
(\text { Know })\end{array}$ & $\begin{array}{c}3 \\
\text { (Know } \\
\text { Enough) }\end{array}$ & $\begin{array}{c}2 \\
\text { (Doubtful) }\end{array}$ & $\begin{array}{c}1 \\
\text { (Do Not } \\
\text { Know }\end{array}$ \\
\hline 1 & $\begin{array}{l}\text { Do you know when a farmer's } \\
\text { institution is established in the } \\
\text { neighborhood? }\end{array}$ & 41 & 9 & 39 & 9 & 2.15 \\
\hline 2 & $\begin{array}{l}\text { Do you know the mechanism of } \\
\text { organizational management of } \\
\text { farmers? }\end{array}$ & 40 & 34 & 15 & 9 & 2.15 \\
\hline 3 & $\begin{array}{l}\text { Are you involved in institutional } \\
\text { management of farmers? }\end{array}$ & 40 & 38 & 12 & 10 & 1.07 \\
\hline 4 & $\begin{array}{l}\text { Are you involved in the proposed } \\
\text { RUKK group activity plan? }\end{array}$ & 43 & 38 & 9 & 8 & 3.22 \\
\hline 5 & $\begin{array}{l}\text { Do you feel the benefits of the } \\
\text { RUKK program through the farmer } \\
\text { institutions in the tertiary irrigation } \\
\text { development program? }\end{array}$ & 66 & 10 & 16 & 9 & 0 \\
\hline 6 & $\begin{array}{l}\text { Does the form of RUKK program } \\
\text { increase the active role of the } \\
\text { management and members of the } \\
\text { farmer's institution? }\end{array}$ & 69 & 13 & 12 & 4.3 & 2.15 \\
\hline
\end{tabular}

Source: Field Study, 2017

Based on the percentage results in Table 3, it was found that $82 \%$ of respondents in this case both in tertiary irrigation aid implementation system were assessed from the farmer institution in the form of their environment. This can be seen from the percentage of respondents' answers to the first question of respondent farmers who answered very know is $41 \%$, enough to know is $9 \%$, know as $39 \%$, hesitate $9 \%$, and do not know is $2.15 \%$. Then the question that both farmers respondents who know very well as $40 \%$, enough know $34 \%$, know is $15 \%$, hesitate is $9 \%$, and do not know is $2.15 \%$. For the third question the farmers who answered very know is $40 \%$, enough know is $38 \%$, know is $12 \%$, hesitate is $10 \%$, and do not know is $1.07 \%$.For the four respondents who answered very well know is $43 \%$, enough know is $38 \%$, know is $9 \%$, hesitate is $8 \%$, and do not know is $3.22 \%$. Then for the fifth question respondents who 
answered very know is $66 \%$, enough to know is $10 \%$, know is $16 \%$, hesitate is $9 \%$, and do not know is $0 \%$. For the sixth question respondents who know very much is $69 \%$, just know is $13 \%$, know is $12 \%$, hesitate is $4.30 \%$, and do not know is $2.15 \%$.

In terms of percentage of respondent answers indicates that farmers are aware of the institutional arrangements of farmers in their neighborhoods, farmers are also familiar with the mechanisms of organizational institutional arrangements. In addition, farmers are also involved in the board and are involved in the proposed group proposals farmers are involved in farmer institutions.

\section{Implementation of tertiary irrigation support system from the assessment of production enhancement}

The results of respondent responses on indicators of increased production can be presented in the following Table:

Table 4. Percentage of respondents answers indicators of increasing production in implementation of tertiary irrigation support in Pohuwato District, 2017

\begin{tabular}{|c|c|c|c|c|c|c|}
\hline \multirow[b]{2}{*}{ No. } & \multirow[b]{2}{*}{ Question } & \multicolumn{5}{|c|}{ Respondents Answer Score } \\
\hline & & $\begin{array}{c}5 \\
(\text { Very } \\
\text { Know) }\end{array}$ & $\begin{array}{c}4 \\
\text { (Know) }\end{array}$ & $\begin{array}{c}3 \\
\text { (Know } \\
\text { Enough) }\end{array}$ & $\begin{array}{c}2 \\
\text { (Doubtful) }\end{array}$ & $\begin{array}{c}1 \\
\text { (Do Not } \\
\text { Know } \\
\end{array}$ \\
\hline 1 & $\begin{array}{l}\text { Do you receive access to tertiary } \\
\text { systems on rice farming? }\end{array}$ & 73 & 12 & 6.45 & 3.22 & 5.37 \\
\hline 2 & $\begin{array}{l}\text { Is the water volume more smoothly } \\
\text { irrigated in tertiary systems on rice } \\
\text { farming? }\end{array}$ & 71 & 9 & 11 & 2.15 & 6.45 \\
\hline 3 & $\begin{array}{l}\text { Is } \mathrm{P} 3 \mathrm{~A} \text { involved in regulating the } \\
\text { distribution of water in tertiary } \\
\text { irrigation channels in wet land rice } \\
\text { farming? }\end{array}$ & 70 & 9 & 14 & 2.15 & 5.37 \\
\hline 4 & $\begin{array}{l}\text { Do you feel the benefit of arranging } \\
\text { the distribution of water in tertiary } \\
\text { systems by P3A? }\end{array}$ & 69 & 9 & 15 & 4.3 & 3.22 \\
\hline 5 & $\begin{array}{l}\text { Does } \mathrm{P} 3 \mathrm{~A} \text {, farmer institution and } \\
\text { management and member of farmer } \\
\text { institution make maintenance } \\
\text { program of tertiary system? }\end{array}$ & 70 & 8 & 13 & 6.45 & 3.22 \\
\hline 6 & $\begin{array}{l}\text { Are you involved in maintaining a } \\
\text { tertiary system? }\end{array}$ & 70 & 10 & 9 & 2.15 & 9 \\
\hline
\end{tabular}

Source: Field Study, 2017

Based on the percentage results in Table 4 , it is clear that $87 \%$ of respondents in this case are very good in tertiary irrigation aid implementation system assessed from tertiary systems that farmers use in rice farming. This can be seen from the percentage of respondents' answers to the first question of respondent farmers who answered very know as much as $73 \%$, enough know as $12 \%$, know as much as $6.45 \%$, hesitant $3.22 \%$, and do not know as much as $5.37 \%$. Then the question that both farmers who answered respondents know as much as $71 \%$, enough to know $9 \%$, know as much as $11 \%$, hesitate as much as $2.15 \%$, and do not know as much as $6.45 \%$. For the third question the farmers who answered very know as much as $70 \%$, enough to know as much as $9 \%$, know as much as $14 \%$, hesitate as much as $2.15 \%$, and do not know as much as $5.37 \%$. For the fourth question respondents who know very much as much as $69 \%$, just know as much as $9 \%$, know as much as $15 \%$, hesitate as much as $4.30 \%$, and do not know as 
much as $3.22 \%$. Then for the question the fifth respondents who answered very know as much as $70 \%$, enough know as much as $8 \%$, know as much as $13 \%$, hesitate as much as $6.45 \%$, and do not know as much as $3.22 \%$. For the sixth question respondents who know very much as much as $70 \%$, enough know as much as $10 \%$, know as much as $9 \%$, hesitate as much as $2.15 \%$, and do not know as much as $9 \%$.

It can be see from the percentage of respondents answers indicates that the system of applying tertiary irrigation aid in Pohuwato District has been very good development, This is seen from the increase of production during the last five years ie in the year of 2012 rice production of 245.786 tons, the year 2013 rice production of 295.913 tons, rice production by 314.703 tons, by 2015 rice production by 331.220 tons, and by 2016 rice production of 337.330 tons. This indicates that there is an increase in production every year, and the implementation of tertiary irrigation assistance has been very good development in Pohuwato District.

\section{Recapitulation of the application system of tertiary irrigation assistance in farmers assessment}

Based on the assessment of the system of applying tertiary irrigation aid from farmers in the indicators of the implementation of tertiary irrigation assistance that is program policy, farmer institution, tertiary irrigation canal and production increase, Can be seen appraisal of tertiary irrigation aid from farmers seen from the highest value of each aid program indicator tertiary irrigation applied in farmers, it can be seen the recapitulation result of the system of tertiary irrigation aid implementation in Pohuwato District in Table 5.

Tabel 5. Recapitulation of the application system of tertiary irrigation assistance in farmers assessment in Pohuwato District, 2018

\begin{tabular}{ccccc}
\hline & Indicator & Score & Percentage \%) & Category \\
\hline 1 & Program Policy & 1,667 & $72 \%$ & Quite Good \\
2 & Farmer Institutional & 2,292 & $82 \%$ & Good \\
3 & Production Enhance & 2,060 & $88 \%$ & Very Good \\
\hline & Total & 6,019 & $80 \%$ & Good \\
\hline
\end{tabular}

Source: Data Processed, 2018

Based on the Table 5 showed that the percentage of the respondents answers total score explained that the program policies applied in the development of tertiary irrigation aid included in the category is quite good, That is the system of application of tertiary irrigation aid in Pohuwato District is good enough applied by farmers, percentage of total score of respondent's answer in see that farmer institute applied in development of tertiary irrigation aid included in good category, meaning that farmer is involved in plan of proposal of group activity on system of application of development program of tertiary irrigation aid, likewise with percentage of respondent score at indicator of production increase including the category of very good, meaning that the implementation of tertiary irrigation assistance can help farmers in increasing rice production in Pohuwato District.

The influence of support program in the development of thermal irrigation canal on rice production improvement in Pohuwato District

Multiple regression result showed in Table 6. Based on the result of multiple regression analysis interpretation below:

1. The constant is $-3,144(\alpha=-3,144)$ 
This number is a constant value of paddy production in Pohuwato District if there is no influence from program policy, farmer institution, and tertiary system (dummy). The negative coefficient result showed that the importance of production input in increasing rice production in Pohuwato District,

2. Regression coefficient X10,710 $(\beta 1=0,710)$

The regression coefficient of program policy variable indicates that every change of program policy is 1 unit then paddy production in Pohuwato District will change 0.710 unit with condition of farmer institutional variable, and tertiary irrigation canal (dummy) in constant (cateris paribus),

3. Regression coefficient X2 0,424 $(\beta 2=0,424)$

The regression coefficient of farmer institutional variable showed that every change in the institutional variables of farmers is 1 unit, then the rice production will change 0.424 unit with the condition of program policy variable, and tertiary systems (dummy) in constant (cateris paribus),

4. Regression coefficient X3 0,890 $(\beta 3=0,890)$

showed that each 1 unit change in tertiary irrigation canal variable, cause rice production change by 0.890 units with the condition of policy program variable and farmer institution in constant condition(cateris paribus).

Table 6. Analysis regression model

\begin{tabular}{cccccc}
\hline Model & \multicolumn{2}{c}{$\begin{array}{c}\text { Unstandardized } \\
\text { Coefficients }\end{array}$} & $\begin{array}{c}\text { Standarized } \\
\text { Coefficients } \\
\text { Beta }\end{array}$ & t & Sig, \\
& B & Std, Error & Beta & \\
\hline (Constant) & $-3,114$ & 1,276 & & $-2,464$ &, 016 \\
Program Policy &, 710 &, 107 &, 470 & 6,666 &, 000 \\
Farmer Institutional &, 424 &, 063 &, 478 & 6,755 &, 000 \\
Irigation System &, 890 &, 416 &, 119 & 2,138 &, 035 \\
(Dummy) & & & & & \\
\hline
\end{tabular}

The following test results coefficient of determination of variables in the research. Based on the Table 7, the value of determination coefficient adjusted R2 is 0,719, This value means that $71,9 \%$ of rice production in Pohuwato District explained by programe policy, farmers institutional, and tertiary irrigation canal, While $28,1 \%$ explained by other factors outside the model. Other factors outside the production function model that are also suspected to have an impact on Rice Production are land fertility level and climate and weather influence and intensity of pests and diseases.

Table 7. Coefficient of determination test result $\left(\mathrm{R}^{2}\right)$

\begin{tabular}{lcccc}
\hline Model & $\mathrm{R}$ & $\mathrm{R}$ Square & Adjusted R Square & Std. Error of the Estimate \\
\hline 1 &, $853^{\mathrm{a}}$ &, 728 &, 719 & 1,98482 \\
\hline
\end{tabular}

F test together simultaneously between independent variables in this case are program policy (X1), farmer institution (X2), tertiary irrigation canal (D) and paddy rice production $(\mathrm{Y})$.

Table 8. Simultaneous test

\begin{tabular}{rlrrrrr}
\hline Model & & Sum of Squares & \multicolumn{1}{c}{ df } & Mean Square & \multicolumn{1}{c}{ F } & \multicolumn{1}{c}{ Sig. } \\
\hline \multirow{4}{*}{1} & Regression & 937,321 & 3 & 312,440 & 79,309 &, $000^{\mathrm{b}}$ \\
& Residual & 350,618 & 89 & 3,940 & & \\
& Total & 1287,939 & 92 & & & \\
\hline
\end{tabular}


Based on the result of analysis in Table 8 obtained the value of F-count of 79,309 with a probability value of 0.000 , because the probability value is smaller than 0.05 then the value of F-count obtained is significant. So it can be said that there is positive and significant influence between independent variable (program policy, farmers institutional, and tertiary irrigation canal) simultaneously to Rice Production in Pohuwato District.

After it is known that there is simultaneously influence then tested partially from independent variable (program policy, farmer institutional, and tertiary irrigation canal) to dependent variable of rice production at Pohuwato District (Table 6).

Based on the results of summary analysis above, the data process showed in this the following result:

\section{The effect of program policy to increasing of rice production in Pohuwato District}

Based on the analysis of positive production regression coefficient indicate that program policy toward increasing rice production through support of tertiary irrigation canal in PohuwatoDistrict is in rational area. Based on t-test value obtained input production program policy amounted to 6.666 which the significance value of program policy $(0.000)$ smaller than probability value 0,05 . So it can be concluded that the program policies have a significant effect on increasing rice production in Pohuwato.

\section{The effect of farmer institutional to increasing of rice production in Pohuwato District}

Based on positive production regression coefficient analysis showed that farmer institution to increase rice production through support of tertiary irrigation canal in Pohuwato district is in rational area. Based on t-test value obtained input of farmer institute production equal to 6,755 which value of institutional significance of farmer (0.000) smaller than probability value 0,05 . so it can be concluded that farmer institution significantly influence to increase rice production in Pohuwato.

\section{The effect of tertiary irrigation canalto increasing of rice production in Pohuwato District}

Based on positive production regression coefficient analysis showed that farmer institution to increase rice production through support of tertiary system in Pohuwato district is in rational area. Based on $t$-test value obtained input of farmer institute production equal to 6,755 which value of institutional significance of farmer (0.000) smaller than probability value 0,05 . so it can be concluded that farmer institution significantly influence to increase rice production in Pohuwato.

Compare with the previous research, the adaptation strategies are very important, all farmers do not use such strategies. The majority of rural households and connected urban populations in developing countries as well as in Pakistan are highly dependent on agriculture. Therefore, adaptation to the negative impacts due to climate variability may be essential to encourage food security for the country and to protect the subsistence of rural households.the increase in irrigation, the increase in evapotranspiration, and the increasing effect of heat stress on crops. Short duration crop varieties, cultivating, and modification in crop sowing time may reduce the negative impact of the aforementioned climatic threats (Singh, 2015).

When the irrigation system become increase, the production of crop alwo will increase too, because it is wompare with the duration of cultivation and to the members of farmer group can have the advantages directly because for the team has implement the irrigation tertiary system in Pohuwato District. 


\section{CONCLUSION AND RECCOMENDATION}

\section{Conslucion}

The system of applying tertiary irrigation suuport from the assessment of the percentage of total score of respondents answers on the program policy indicators included in the category is good enough, the indicators of farmer institutions are included in the good category, and the indicators of increasing production are included in very good category, so the application of tertiary irrigation aid in the research sites have been well developed through the assistance of tertiary irrigation canal program.

Based on the results of multiple linear regression testing found that: a) Program policies have a significant effect on rice production in Pohuwato District. The regression coefficient for program policies has a positive effect on rice production. Positive production elasticity indicates that the program policies implemented in the assistance of development programs of tertiary systems are in rational area; b) The farmer institution significantly influences rice production in Pohuwato District. The positive regression coefficient indicates that farmer institution is in rational area; c) The tertiary system has a significant effect on rice production in PohuwatoDistrict. The regression coefficient for tertiary irrigation canal has a positive effect on rice production. Positive production elasticity indicates that the tertiary irrigation canal of rice cultivation is in a rational area because the use of irrigation canals can increased rice production.

\section{Recommendation}

The utilization of tertiary irrigation canal by farmers in the sample area in particular and in tertiary irrigation canal land in Pohuwato District generally need to be optimized by applying the system and application of good tertiary irrigation canal management.

Improvement and continuation of development assistance program for tertiary system must be oriented to increase rice production through effective and efficient program and principle of financial approach so farmers can allocate other production costs, without neglecting the system and operational management of tertiary irrigation canal in sample region.

Tertiary systems can be classified on the production factors of wetland rice farming, therefore this production factor is expected to be an important part of research on science development and development program of tertiary irrigation canal in Pohuwato District in the future.

\section{REFERENCES}

Abeysingha, N.S, man Singh, Addul Islam, V.K, Seghal. (2016). Climate Change Impact on Irrigated rice and Wheat production in gomti river basin of India: a Case Study. Springerplus. 2016; 5(1): 1250. Published online 2016 Aug 3. doi: 10.1186/s40064-016-2905-y

Ali, Sajjad, Ying Liu, Muhammad Ishaq, tariqSaleh, Abdullah, AasirIlyas, IzharUd Din. (2017). Climate Change and Its Impact on the Yield of MajorFood Crops: Evidence from Pakistan. www.mdpi.com/journal/foods. Foods 2017, 6, 39; doi:10.3390/foods6060039

Daniel, (2004), Pengantar Ekonomi Pertanian, Bumi Aksara, Jakarta,

Dewi Arifianti Agustina, Subari. (2011). Potensi Kearifan Lokal Dalam Kelembagaan Pengelolaan Irigasi Di Pulau Jawa. Jurnal. Penelitian Bidang Irigasi Pusat Litbang SDA Badan Litbang PU, Bekasi. 
Gujarati, I, (2006), Ekonometrika Dasar, Erlangga: Jakarta,

Helmi. (2007). Peranan Lembaga P3A/Kejruen Blang Dalam Konteks Otonomi Daerah Tentang Pengelolaan Air Irigasi Di Provinsi Aceh. Jurnal. Fakultas Pertanian Unsyiah Darusalam, Banda Aceh.

MOA (Ministry Of Agriculture) Technical Team, Gerald M. Fuller, Bruno Strebel, Sizi Z. Subah, James T. Moore. (2015). Rehabilitation and Development of Itegrated Lowland Rice Farming in Liberia. http://inter-reseaux.org/IMG/pdf/ctechnical_manual_lowland.pdf, Access On July $5^{\text {th }} 2018$

Spiegel, M,R, dan L,J, Stephens, (2004), Statistik, Erlangga, Jakarta,

Sudjana, (2002), Metoda Statistika, Penerbit PT Tarsito, Bandung

Sugiyono, (2014), Metode Penelitian Kuantitatif kualitatif dan R\&D, ALFABETA,CV, Bandung,

Trisno. (2009). Otonomi Daerah Dan Kelembagaan Irigasi Dalam Penatagunaan Air. Jurnal. Pertanian Bengkulu.

Trinh, Mai Van (IAE/VAAS), Nguyen Van Bo (VAAS), Hoang Gia Minh and Nguyen XuanDzung (CETDAE), UdayaSekharNagothu and TrondRafoss (Bioforsk), Andrew Borrell (The University of Queensland, Hermitage Research Facility) and Bui Huy Hop (MoST). Climate change and impacts on rice production in Vietnam: Pilottesting of potential adaptation and mitigation measures. http://www.bioforsk.no/ikbViewer/Content/111600/Deliverable\%201\%20\%202 \%20Bench\%20mark\%20report.pdf. Access On July $5^{\text {th }} 2018$. 